\title{
Vocational Training on Wood Carving in Kete Kesu Village, North -Toraja Regency
}

\author{
Sofyan Salam*, Tangsi, Muhammad Saleh Husain \\ Universitas Negeri Makassar \\ Makassar, Indonesia \\ sofyansal@unm.ac.id
}

\begin{abstract}
This research is an effort to document the practice of wood carving vocational training in Kete Kesu, North Toraja. The purpose of this article is to describe the practice of wood carving training, including the place and participants, training methods, and comparisons between current and past training. This research used a case study method with data sources from the people involved (trainers, trainee, and community leaders), training activities, artefacts and the equipment. Data were collected through observation, in-depth interviews, and documentation. The data were analyzed qualitatively to answer the research questions. The findings of the research are (1) wood carving vocational training activities in Kete Kesu, was based: in households and within the scope of neighbors, where members teach each other the skills in wood carving they have. (2) the training method used is the imitation method where the trainees imitate the skills practiced by the trainer; (3) There is a difference between the practice of wood carving vocational training in the past and the present due to changes in the lives of the people of Kete Kesu.
\end{abstract} Toraja

Keywords—craft training, wood carving, Kete Kesu village,

\section{INTRODUCTION}

The Government of the Republic of Indonesia has a constitutional responsibility in advancing Indonesian culture as mandated by the 1945 Constitution. Article 32 paragraph (1) of the Constitution of the Republic of Indonesia states that "The State advances Indonesian National Culture ..." One of the challenges faced by the government in carrying out this mandate is to record various aspects of Indonesian culture, both past and present.

This research was conducted in the context of the documentation effort, especially in the field of traditional education, by documenting the traditional education practices that took place among the carvers in Kete Kesu. Kete Kesu is a village in Rantepao District, North Toraja Regency, South Sulawesi Province. As a village, Kete Kesu has a distinctive appeal because apart from the fresh and cool climate because it is covered by mountains and rice fields. Kete Kesu also presents various aspects of Toraja culture. Kete Kesu is a village that has a history as an old residential area which until now still perpetuates old traditions. Life in Kete Kesu is a life that is very colored by the typical Toraja culture related to its original belief, Aluk todolo, which means religion/ancestral rules [1]. Aluk Todolo instilled awareness for Toraja people that life in this world is temporary and the afterlife is the real destination. The peculiarity of the Kete Kesu settlement is what makes UNESCO awarded the village as a cultural heritage [2].

The traditional education in Kete Kesu which is documented in this study is the practice of vocational training in traditional wood carving. Kete Kesu is very well known as a producer of unique and artistic wood carvings. The wood carvers at Kete Kesu work individually or in groups. The wood carvings they produce consist of: (1) wood carvings for sacred purposes that are used to decorate traditional houses (tongkonan), rice barns (alang) and coffins; (2) wood carving for souvenir purposes for tourists. The carvers' skill in carving at Kete Kesu, passed down from one generation to the next Documenting the practice of vocational training in traditional carving that took place in Kete Kesu is important because this has never been done, so there is no written information about it. This research aims to produce documentation work on "educational practices" that can be used as study material to perceive educational values in educational practices which can then be used as a reference and source of inspiration in efforts to preserve traditional education, especially in the field of carving. In addition, the results of this study are also expected to be used as a comparison with traditional educational practices in other places in order to gain a comprehensive understanding of traditional education.

Appertaining to the descriotion, this study focuses on answering three research questions; (1) Where is the carving training held and who are the trainers and trainees? (2) How is the carving training method applied? and (3) How does the comparison between past and present wood carving training?

\section{LITERATURE REVIEW}

\section{A. Craft Apprenticeship}

In pre-modern Indonesian society which is popularly known as traditional society, vocational training takes place informally in the form of apprenticeship. Singleton defined apprenticeship in a broad sense as "any situation where a 
novice learns from someone who is more expert" [3]. Apprenticeship begins with an expert in a certain field who is approached by young people to learn by staying with the expert for a certain period of time according to their needs. The expert who acts as a teacher is highly respected by his students. As a training system, apprenticeship is the oldest education system. Apprenticeship systems develop naturally in line with the desire of a person or group of people to acquire knowledge or skills from an expert in a particular field. Since the apprenticeship system grows and develops according to the cultural environment, it is not surprising that there are so many local terms for apprenticeship activities. In Javanese society, the term pencantrikan which is derived from the word cantrik, means pupil of an expert or bengawan. Soehardjo stated that in Javanese, the term nyantrik means work or work performed by novice workers under the guidance of an expert [4]. In the Bugis community, the term makkanre guru is synonymous with apprenticeship. Other local terms that are synonymous with apprenticeship are patapaan santri (Sundanese) and baraja (Minang). Apart from the naming aspect, there are also variations in the procedures for recruiting students and their requirements, the duration of activities, social interactions, learning materials and methods, and so on

The apprenticeship system can basically be divided into: (1) an informal apprenticeship system that takes place naturally based on the spirit of mutual understanding between teachers and students commonly in traditional Indonesian society; and (2) a formal apprenticeship system that is legally regulated as defined in the ILO report as "any system by which an employer undertakes by contract to employ a young person and to train him [or her] or have him [or her] trained systematically for a trade for a period the duration of which has been fixed in advance and in the course of which the apprentice is bound to work in the employer's service" [5]. This definition of formal apprenticeship mentions several characteristics of formal apprenticeship, such: based in the workplace supervised by an employer; intended for young people; fundamental aim is learning a trade/acquiring a skill; training is "systematice i.e., follows a predefined plan; and governed by a contract between apprentice and employer.

Craft is one of the areas of expertise taught in the apprenticeship system. This is reasonable because the field of craft that requires various types of materials used is a field that requires complex technical skills to master. The need for craft work is increasing with the development of society, making apprenticeship grew rapidly. Soehardjo stated that the traditional apprenticeship system in the handicraft sector is still ongoing today as can be seen in Bali, although there have been changes in apprentice's motivation to learn. According to Soehardjo's observations, students who came for internships had a dual purpose; to study and work in order to get reward. Generally, these students come from community groups with low-income households [6]. As happens in apprenticeship practices elsewhere, students who came to learn started their activities with the basics such as preparing materials and work equipment [7]. The learning method that was commonly used in craft apprenticeship is the imitation method, where the teacher shows how to do something which is then imitated by the student until he is proficient [8].

\section{B. Toraja Wood Carving}

Since the prehistoric periods, the art of carving has become a form of artistic expression in various ethnic communities in Indonesia. As a form of artistic expression in a society whose life is filled with animism or dynamism beliefs, the art of carving also reflects animism and dynamism views. Jaszi argued that in Indonesian society, art is an integral part of social life. Important events in the life of individuals and groups are marked by artistic expression, both religious and secular [9]. On this basis, Indonesian traditional artists view the works of art they create as a reflection of social relationships that aim to maintain and strengthen meaningful patterns of social life. Carving as a form of craft has a function as stated by Enget et al namely: (1) personal function to fulfill personal satisfaction; (2) social functions related to society functions including culture and beliefs, and (3) physical functions related to practical needs for daily necessities [10].

The art of carving made by craftsmen in Toraja has the same character as the traditional carving art in Indonesia, which is a reflection of the people's view of life, in this case the Toraja people. Toraja society today is a society that has cultural roots based on the original belief of the Toraja people, Aluk Todolo which means ancestral rules. Even though today the Toraja people have adopted Christianity, Catholicism, or Islam, the teachings of Aluk Todolo still strongly influence their lives. The essence of Aluk Todolo's teachings is the worship to glorify Puang Matua (the Creator) in the form of ritual offerings [11]. In Toraja, the art of carving is known as passura which means writing. It reflects the original function of Torajan carving as a symbol of the expectations of the Toraja people for a safe and prosperous life through symbolic carving motifs according to Aluk Todolo's belief. This kind of carving art adorns the famous Toraja traditional houses, the tongkonan and alang, as well as the coffins (erang). Visually, Toraja carving art has unique characteristics that make it easy to recognize, such as flat surface, colorful with black as the basis. The motifs are typical. Carving materials that are commonly used are wood, bamboo and stone [12]. The unique Toraja carving art with sacred and symbolic motifs is still made especially to fulfill the need for traditional tongkonan and alang house decorations, as well as coffin decorations (erang).

Recently, in Toraja, a new type of wood carving has emerged. The wood carving is developed from the materials and working techniques from the traditional method but with decorative motifs that are no longer sacred according to Aluk Todolo's belief. These nonsacral motifs were born as the carvers response to new needs stimulated by the developing tourism. Travelers who are interested in enjoying the uniqueness of Toraja culture want souvenirs that typically describe the exoticism of Toraja culture. Narrative motifs were born with various themes which were essentially to introduce the typical life of the Toraja people. 


\section{METHODS}

This research is a case study with a qualitative approach to reveal the practice of implementing wood carving training in Kete Kesu, North Toraja. The study focuses on wood carving training venues and the parties involved, training methods applied in wood carving training, and comparisons between wood carving training in the past and the present time. The data sources for this research are people, activities, and artifacts. Sources of human data consist of expert carvers as trainers, novice carvers as training participants, and community leaders who have in-depth knowledge of current and past vocational training practices in wood carving. Sources of activity data are the works that take place in the carving training process. The sources of the artifact data are the productions of wood carvings made during the training process. Data collection was carried out through (1) participatory observation was conducted by observing and participating as training participants, and indepth interviews. The data were analyzed qualitatively to build a description of the research focus.

\section{RESUlTS AND DisCUSSION}

\section{A. Findings}

From data collection, the wood carving training in Kete Kesu currently took place in two spots: (1) in the household which involve the head of the household (grandfather, father, mother) who are skilful in wood carving as trainers and young family members (children, nieces, and other family members) as participants. There are many carving training households in Kete Kesu. The training participants involves both male and female in the family. (2) within the neighboring group. The training that takes place in a neighboring group environment was basically wood carving training by a peer group. Teenagers who learn wood carving at home under the guidance of their parents or grandparents, when making carvings on their backyard, are approached by their peers who are interested in learning to carve as well. The learning-teaching process of wood carving between peers consists of the techniques of holding a carving knife properly, making carving patterns with prticular decorative motifs and colouring. Socially, the relationships between members who teach and those who are taught are equal because they are peers. The knowledge and carving skills taught are relatively basic and simple, for example for souvenir purposes in the form of wall decorations with traditional Toraja motifs.

Regarding the learning method applied, it was found that the learning method in wood carving training in Kete Kesu is in an atmosphere of informal interaction between the trainer and the participants. Technically, the learning method applied is the imitation method. In training activities, participants duplicate what was performed by trainers. Learning activities revolve around observations by participants, both casual observations and focused observations of what senior carvers were executed. Because the learning activities are informal, the trainers do not make certain preparations for learning. They only allowed the participants to observe or ask questions. What was observed is then continuously practiced under the coach's direction and supervision. Carving practices begin simply with preparing tools and materials to engrave and coloring exercise. The primary lesson for the participants required to be mastered is how to hold and utilize a carving tool (in the form of a taper and sharp knife) in order to produce good carvings. Besides, by properly holding and controlling the carving knife, the engraver will avoid the risk of being wounded. During the observation, one of the participants was injured for being hasty in using a carving knife. How to hold and control the carving knife properly must become an ingrainedan ingrained habit for a carver. Otherwise, the danger of getting cut looms large at any time. After the participants master how to hold and utilize a carving knife, then they can be trained to carve with certain decorative motifs, starting from simple decorative motifs such as straight-line motifs. From straight-line motifs, the exercise continues to curve lines and circles. In line with carving exercises, participants are taught how to maintain and sharpen carving knives. Coloring is the next learning material. The apprentices learn how to prepare natural dyes (charcoal, limestone, and soil) and brush the colors using a special (selfmade) brush. They are also taught about the symbolic meaning of color, although it is not so thoroughly.

Regarding the comparison between the current wood carving training and the training that took place in the past, it was found that in Toraja, there were carvers with tomanarang status. Tomanarang is carver who was highly respected because of their carving skills and understanding of Toraja custom and beliefs, Aluk todolo. Carvers with tomanarang status were visited by people from outside the village to carve in the past. Therefore, tomanarang taught their carving skills to his family members, and also other people outside his household. An elderly carver (73 years old) said that his father, Nek Kambane, was a tomanarang. He learned to carve directly from his father. The types of carvings he studied were carvings with symbolic and sacred decorative motifs. Apart from himself, there were also many people came to learn, all of whom had Torajan ethnic backgrounds. Actually, people from other ethnicities are also accepted, but only Toraja people are attracted. It is interesting to note, that the Torajan who learned to carve were those from among the common people. The aristocracy were not interested in carving because the work of carving was considered unsuitable for them. Carving training are based on sincerity to teach skills to others. Someone who wants to train to carve without being burdened with payments from the learners. The training activities do not have a fixed schedule and take place any time during the day according to the student's opportunity. For lunch, the trainees returned to their homes. Because of its informal nature, there are no stipulated requirements for student admission, educational period, and competency requirements. Trainees come and go as they please. Nowadays, carvers with tomanarang status are no longer exist, and carving skills have become popular in Kete Kesu. Therefore, training activities are spread across many households or neighborhoods. The types of carvings created today are varied because they include non-sacred carvings with decorative motifs for souvenir purposes. As happened in the 
past, participants of wood carving training are not burdened with payment in the present time.

\section{B. Discussion}

The findings of the location, subjects and parties involved in wood carving training activities in Kete Kesu indicate that carving training is popular in the community. The training in apprenticeship activities is following Singleton's definition; a situation where a beginner learns from someone more skilled. It categorized by the ILO as an informal apprenticeship where apprenticeship activities take place within households and neighboring groups.

The findings of the learning methods applied seem to be a universal method applied in the practice of craft education in various parts of the world. Houghton explained that from a study of the literature it is known that the most effective method of craft education is through demonstration, observation, and continuous practice [13]. Therefore, it can be said that the learning methods practiced by the carving teachers in Kete Kesu are adequately executed. The uniqueness of the learning methods applied in the craft-carving arts education at Kete Kesu lies in the technical peculiarities of engraving such as the way to use a distinctive carving knife, engraving specific decorative motifs, and coloring.

Comparative description of the implementation of wood carving training in the past with the present reflects the changing era. Nowadays there are no carvers with the status of tomanarang who are highly respected because of their deep understanding of Toraja culture and Aluk todolo's beliefs. The large number of households that have become carving apprenticeships shows the spread of carving knowledge and skills among community members. In the past, wood carving training were concentrated in the residence of the tomanarang carver.

\section{CONCLUSIONS}

Wood carving training in the village of Kete-Kesu takes place in a (1) household. The head of the household (grandfather, father, or mother) teach the carving skill to their family members; and in (2) a neighborhood where the youth shared carving skills among their group members.
The learning method applied in wood carving training is the imitation method, where participants duplicate carving techniques performed by senior carvers. This imitation method is universal in apprenticeship pursuits.

Compared to the practice of wood carving training in the past, nowadays there are no more skilled carvers with tomanarang status who are highly respected and visited by many people to learn carving, including people outside the family members. In the past, the residence of the tomanarang was the center for wood carving training. On the contrary, at this time, wood carving training places spread in many households because at this time wood carving skills are increasingly popular, especially for tourism purposes.

\section{REFERENCES}

[1] L.T. Tandilingtin, Toraja dan Kebudayaannya. Makassar: Lembaga Kajian dan Penulisan Sejarah Budaya Sulawesi Selatan, 2014, p. 54.

[2] UNESCO. Evaluation of Cultural Properties. Paris: Icomos. 2001. p. 90

[3] D.E. Lancy, "First you must master Pain: The nature and purpose of apprenticeship.”Antthropology of Work Review. Vol XXXIII, No. 2, pp. $113,2012$.

[4] A.J. Soehardjo, Pendidikan Seni: dari Konsep Sampai Program. Malang: UM, 2005, p. 8

[5] ILO, Overview of apprenticeship systems and issues. Geneva: ILO, 2012, p. 12

[6] A.J. Soehardjo, Pendidikan Seni: dari Konsep sampai Program. Malang: UM, 2005, p. 10.

[7] A.D. Efland, A History of Art Education. New York, London: Teacher College Columbia University, 1990, p. 23.

[8] A.J. Soehardjo, Pendidikan Seni: dari Konsep Sampai Program. Malang UM, 2005, p. 11.

[9] P.I. Jaszi, Traditional Culture: A Step Forward for Protection in Indonesia - A Research Report. Jakarta: Institute for Press and Development Studies, 2009, p. 6-7.

[10] Enget, Kriya Kayu. Jakarta: Depdiknas, 2008, p. 1-3

[11] L.T. Tandilingtin. Toraja dan Kebudayaannya. Makassar: Lembaga Kajian dan Penulisan Sejarah Budaya Sulawesi Selatan. 2014. p.54.

[12] S. Salam, M.S. Husain, and Tangsi. Seni Ukir Tradisional Ke'te Kesu' Toraja Utara. Makassar: Penerbit UNM, 2016, p. 6.

[13] N. Houghton, "Craft education: what it is, where it comes from, where it’s going” Making Futures, ISSN 2042-1664, 2013, p. 17. 